\title{
DIE ANTWOORD EN TAAK VAN DIE KERK TEN OPSIGTE VAN SEKULARISASIE
}

\author{
PROF. DR. B. J. ENGELBRECHT *
}

1. Uit die vorige lesings van hierdie predikantevergadering het dit geblyk dat sekularisasie ' $n$ begrip is met ' $n$ verskeidenheid betekenisse. Dit is egter my oortuiging dat hierdie betekenisse basies met mekaar saamhang. Basies beteken sekularisasie dat hierdie sigbare ervaarbare wêreld in al sy fasette én hierdie samelewing en al sy lewensgebiede onttrek word aan die leiding, invloed en seggenskap van die "sakrale" wêreld (of sfeer). Hierdie wêreld en samelewing wil dan in terme van hulleself verstaan en beleef word. In die nie-christelike, sg. primitiewe samelewing ên in die Christelike wêreld van vóór die Renaissance bestaan daar ' $n$ eenheidskultuur. Kenmerkend van hierdie eenheidskultuur is dat daar twee wêrelde is, naamlik hierdie sigbare en ervaarbare wêreld, en die goddelike wêreld van sakrale persone, magte en ruimtes. Eintlik is hierdie goddelike wêreld die basiese, bepalende en singewende grond t.o.v. hierdie sigbare, ervaarbare wêreld, geskiedenis en tyd. Die sin van hierdie wêreld én van al die denke, spreke en handel van die mens, word bv. bepaal deur die oertyd (laat ons dit skepping en sondeval noem) én deur die eindtyd (laat ons dit oordeel en hiernamaals noem) én deur die gedurige ingrype van die Hoër Wêreld en Magte in hierdie wêreld en geskiedenis (laat ons dit die heilsgeskiedenis en voorsienigheid van die Lewende God noem). Hoe taai hierdie oortuiging is van die bepaling van hierdie wêreld en lewe deur die wêreld en magte daarginds en daarbo, blyk bv. uit die taaiheid van die bygeloof by ons Bantoes, nieteenstaande alle wetenskaplike vooruitgang en pogings tot kerstening. Maar ook in die Christelike geloof hang alles eintlik hiervan af. Dit is bekend hoe die Bybel bv. in I Kor. 15 die hele Christelike geloof en al die implikasies daarvan vir ons lewe laat afhang van die opstanding van Jesus Christus en die hiernamaals. Indien die hiernamaals wegval, dan val die hele Christelike geloof en alle etiese inspanning en verantwoordelikheid weg, en dan is die beste lewensfilosofie: "Laat ons dan maar eet en drink, want môre sterf ons" (I Kor. 15 vs. 32). Die verleiding is groot om feitlik die hele Psalm- en Gesangboek met $u$ deur te gaan om hierdie basiese oortuiging en motief daar te stel. Laat ons net twee voorbeelde noem $\mathrm{nl}$.:

* Voordrag gehou by Predikantevergadering Ned. Herv. Kerk, Pretoria,

2 Oktober 1968. 
(a) Ges. 43 vers 1:

„Hoog, omhoog, die hart na bowe,

Waar ons Heer en Heiland is!

Waarliik lewe, liefhê, lowe,

Kan ons slegs waar Jesus is.

Wat ons hoor en sien op aard,

Is ons kosbaar hart nie waard;

Wil ons lewe, liefhê, lowe, -

Hoog, omhoog, die hart na bowe!"

(Vergelyk veral ook vs. $2-6$ ).

(b) Ges. 189 vers 6:

"Diê hoop bring in ons leed versagting;

Kom, reisgenoot, die hoof omhoog!

Die Heer, ons ewige verwagting,

maak berge vlak en seë droog.

o Saligheid, nie af te mete,

o vreugde ver bo ons verstand:

dáár is die vreemd'lingskap vergete,

dáár is ons in die Vaderland!"

En eintlik is die hele Openbaringeboek één magtige beligting van hierdie lewe en geskiedenis vanuit die wêreld van God en vanuit Sy nuwe bedeling. Die eenheidskultuur waarvan ons gepraat het, bestaan daarin dat alle fasette van hierdie wêreld, lewe en geskiedenis tot 'n eenheid saamverbind word deur hierdie ander wêreld van God.

2. Laat ons net eers 'n misverstand uit die weg ruim en stel dat ons hier nie die Christelike Godsgeloof, Skeppingsgeloof, Voorsienigheidsgeloof en Toekomsverwagting gelyk stel met dié van ander godsdienste $\mathrm{nl}$. die primitiewe godsdiens nie. Ons wys hier slegs op 'n formele struktuur wat by beide die Christelike én primitiewe godsdiens teenwoordig is.

3. Nadat ons dit nou gestel het, kan ons net weer herhaal dat sekularisasie beteken dat hierdie sigbare, tasbare en ervaarbare wêreld in al sy fasette en sektore en hierdie samelewing met al sy lewensgebiede en funksies onttrek word aan die invloed, leiding en seggenskap van die "sakrale" wêreld en in terme van homself verstaan en beleef wil word. In hierdie proses wil ek onderskei tussen die onttrekking van.

(a) die Christelike, westerse wêreld, en

(b) die heidenwêreld en bygeloof;

(c) die Christelike geloof en godsdiens. 
4. Daar is dikwels daarop gewys dat die Bybelse openbaring van die één, enige waaragtige God en Sy diens (Deutr. 6 vs. 4 en 5) die grootste eksorsis en "sekulariseerder" van alle tye is :

(a) Die implikasies van die eerste en tweede gebod in hierdie verband, is duidelik en onder andere in Jes. 40 vers 12-26; 41 vers $29 ; 44$ vers $6-23$ en Jer. 10 vers $1-16$ word dit aangrypend en duidelik beskrywe dat alle afgode "nietighede", .nikse" is, dit wil sê objektief bestaan hulle glad nie maar hulle is slegs skeppings van die sondige mens se hart en hande. Subjektief bestaan die afgode wel, en het hulle 'n magtige invloed, maar objektief is daar maar één God en subjektief eis Hy ons totale eksistensie in Sy diens op.

(b) Ook in die Nuwe Testament vind ons dieselfde gedagte ten opsigte van die afgode en bygeloof. I Kor. 1 vers 4-6 en 10 vers 19-20 sê bv. dat die afgode en afgodsoffer objektief niks is nie, terwyl I Kor. 6 vers 13 met die uitspraak dat die voedsel vir die maag en die maag vir die voedsel is, die hele skepping as't ware met groot geloofsnugterheid losmaak van die geweldige ban van die afgode en bygeloof en dit slegs as eenvoudige geskape werklikhede beskrywe.

(c) Die Godsopenbaring van $\mathrm{Ou}$ en Nuwe Testament is dus 'n groot en magtige reduksie ten opsigte van alle afgodediens, bygeloof, valse godsdienstigheid en valse vroomheid.

(d) En ook die Kerkhervorming het met éên magtige pennestreep vanuit die sola scriptura, sola gratia en sola fide baie eeue van Kerkgeskiedenis, bygeloof en valse vroomheid gerojeer. En nou vra die aanhangers van die sekularisasie (bv. John A. T. Robinson, The New Reformation 1965) of "sekularisasie" ten opsigte van die heidenwêreld, maar dan ook ten opsigte van die Christendom en Christelike Geloof, nie ' $n$ konsekwente, noodwendige en wettige voortsetting van bv. die Kerkhervorming van die sestiende eeu is nie?

5. Die vraag egter wat my hier gedurig hinder, is of ons in die Bybelse eksorsisme ten opsigte van die heidenwêreld en ten opsigte van alle bygeloof wel met sekularisasie in eintlike sin te doen het? Moet ons hier nie liewer praat van die ontdemonisering en ontmitologisering van die ganse geskape kosmos nie? Want wat ons hier het, is dat die wêreld hier deur die Bybel en Kerkhervorming nie losgemaak word van die demoniese en mitologiese 
magte om in eie terme verstaan en beleef te word soos dit in die sekularisasie die geval is nie, máár dat dit van die sataniese en demoniese magte ontbind word om nou eers reg in die diens en onder die heerskappy van God gestel te word. Christus se heilswerk word dikwels in die Bybel (bv. in die Openbaringeboek en in die genesingswonders) as die oorwinning oor die demoniese en sataniese magte beskrywe. Dikwels word hierdie magte in die Bybel beskrywe as die magte van die sonde, die wet en die dood. Maar die evangelie van verlossing is juis dat ons wat slawe van die demoniese magte van die sonde, wet en dood was, juis deur Christus vrygemaak word tot diensknegte van God en deur die Heilige Gees tot Sy kinders en erfgename. Rom. 6 vers 22 sê uitdruklik :

.Maar nou dat julle vrygemaak is van die sonde en diensbaar geword het aan God, het julle jul vrug tot heiligmaking en uiteindelik die ewige lewe"

(vgl. ook Rom. 6 vers 18 en 8 vers 2 en 21). Ons hoef nie hier daarop te wys watter geweldige konsekwensies Jesus Christus se opstanding en hemelvaart as oorwinning oor die magte van dood en verganklikheid vir hierdie lewe én vir die ewige lewe het nie. Kortom: Hier is myns insiens geen sprake van sekularisasie nie, maar wel van ontdemonisering, van die losmaking van die skepping van die demoniese magte vir God, vir Sy wêreld en diens. Dit is waar dat die gelowige groot vryheid ten opsigte van die geskape werklikheid bekom deur in die lig van Gods Woord te besef dat hierdie dinge nie gode is nie, maar geskape werklikhede. Maar aan die ander kant word hierdie dinge resloos in die diens van God gestel. Dieselfde apostel wat in I Kor. 6 vers 13 die bevrydende woord spreek dat die voedsel vir die maag en die maag vir die voedsel is, sê in dieselfde brief (I Kor. 10 vers 31): .Of julle dan eet of drink of enigiets doen, doen alles tot verheerliking van God". En in dieselfde I Kor. 10 waar Paulus sê dat die afgode en afgodsoffer niks is nie, erken hy die bestaan van Satan en die demoniese magte en in Rom. 6 vers $18-22$ en 8 vers 2 en 21 waar hy met evangeliese vreugde die vryheid ten opsigte van die demoniese magte van sonde en dood deur die oorwinning van Christus aankondig, dáár erken hy die wêreld van God (nl. God, die engele, die hemel en die ewige lewe) wat hierdie wêreld en lewe beslissend bepaal.

6. Wat die sekularisasie van die Christelike westerse wêreld en kultuur betref, het ons alreeds daarop gewys dat vóór die Renaissance daar in eenheidskultuur was waarin alle lewensgebiede saamgebonde gestaan het onder die seggenskap, invloed, leiding, troos en tug van die Christelike geloof. In die Middel-eeue 
het dit prakties beteken die invloed en leiding van die Rooms Katolieke Kerk wat sigself as plaasvervanger van Christus en Sy koningsheerskappy op aarde gesien het. Maar met die Renaissance begin allerlei funksies en lewensgebiede (bv. die wetenskap, die kuns, die ekonomiese en politieke lewe, die regspraak en die onderwys) hulle loswikkel van die binding aan die Kerk en begin hulle 'n eie outonomie te verkry en begin hulle leef vanuit eie dryfkragte en eie norme. In 'n sekere sin is die Kerkhervorming ook hierby betrokke, omdat dit ook 'n loswikkeling is van die gelowiges en gemeentes van die Rooms Katolieke se kerklike seggenskap en gesag. Maar die Kerkhervorming het die gelowige en geloofsgemeenskap nie losgewikkel van die gesag en seggenskap van Gods Woord nie, terwyl die genoemde lewensgebiede én funksies hulle óók losgewikkel het van die seggenskap van Gods Woord, van die Christelike geloof en die teologie.

7. Hieruit is dit duidelik dat wat die Kerkhervorming betref, dit nie werklik sekularisasie was nie. Die outonomie (eie wettelikheid), eie norme, stukragte en mondigheid van bogenoemde lewensgebiede was myns insiens wel sekularisasie in eintlike sin. Sommige mense beskou hierdie sekularisasie as 'n wins, veral gesien die geweldige opbloei en ontplooiing van hierdie wetenskapsgebiede. Myns insiens doen ons hier goed om te onderskei tussen die losmaking van hierdie lewensgebiede ten opsigte van die middeleeuse wetenskapsbeskouing van die Roomskatolieke Kerk se gesagsstruktuur en die eintlike sekularisasie as strewe na outonomie, ook los van Gods Woord en die Christelike Geloof. In elk geval is dit duidelik dat vanweë hierdie sekularisasieproses daar vir die Kerk en Teologie wat uit Gods Woord wil leef, ook vandag geweldige probleme geleë is.

(a) Eerstens is daar die opbreking van die geestelike lewe van die mens in 'n norring afsonderlike vakgebiede wat dikwels in waterdigte kompartemente van mekaar leef. Die moderne mens voel homself bedreig en verdwaald omdat sy lewe as't ware versplinter en uitmekaargeskeur is in 'n onoorsigtelike veelheid waarin hy geen verband en werklike eenheid kan vind nie.

(i) Schleiermacher het byvoorbeeld dit aangevoel en gevind dat die verskillende wetenskapsgebiede die totale mens en al sy funksies opgeëis het (bv. sy verstand, wil en doen). Die godsdiens is as't ware uit die lewe verdryf en baie mense het gevoel dat die godsdiens vir die moderne mens uitgedien is en geen funksie meer vir die mens te vervul het nie, met ander woorde hulle het volkome gesekulariseerd 
geraak. En nou mag 'n mens ernstige bedenkinge teen Schleiermacher se metode en oplossings hê, maar één verlange by hom verdien positiewe waardering en dit is dat hy wou aantoon dat die godsdiens wel ' $n$ wesenlike plek en funksie in die mens se lewe en samelewing het en behoort te hê. In sy magistrale boek .,Toesprake oor die Godsdiens aan die intellektueles onder haar veragters" van 1789 , het hy vir ' $n$ volkome geskulariseerde wêreld, vir wie God en Sy wêreld daarbo en daarginds géén betekenis meer gehad het nie, probeer aantoon dat die godsdiens tog wel 'n „eigene Provinz", 'n eie onaantasbare plek in die menslike lewe het, naamlik die Gevoel, die gevoel van absolute afhanklikheid van die Ander.

(ii) Eintlik was Schleiermacher se oplossing nie nuut nie, want na die kerkhervorming het die kerk hom dikwels van die gesekulariseerde lewensgebiede en -funksies teruggetrek en al meer-en-meer klem gaan lê op die persoonlike geloof, vroomheid en godsdiens binne die ruimte van die kerk, terwyl die kerk wantrouig gaan staan het ten opsigte van ,die wêreld," dit wil sê ten opsigte van bv. die politieke en maatskaplike gebiede. Die kerk het sodoende eintlik die outonomie van hierdie lewensgebiede erken en hom toegespits op sy interne taak. Maar daarmee het die kerk (en wat erger is : die Christelike Geloof) - en dan slegs in gunstige gevalle maar één van die baie fasette van die menslike lewe geword wat dikwels moes kompeteer met ander fasette bv. met die vermaaklikheidswêreld. In hierdie kompetisie het die kerk dikwels in die ander uiterste verval deur vir ander lewensgebiede te sê: „Wat jy kan aanbied kan ek beter aanbied!" bv. in die Social Gospel ten opsigte van die politieke lewe.

(b) ' $n$ Ander probleem (behalwe die versplintering van die lewe, maar wat onlosmaaklik hiermee saamhang) ont. staan uit die vraag: .Maar het hierdie lewensgebiede wat mondig en gesekulariseerd geraak het en hulle van die Woord van God, die Christelike geloof, die kerk en die Teologie se seggenskap onttrek het, dan nie eie outonomie, stukragte en norme nie? Kan die kerk werklik in positiewe bydrae tot bv. die wiskunde of die letterkundige kritiek lewer of moet die kerk dit nie liewer aan 
vakmanne oorlaat om vanuit hulle eie spelreëls $(=$ norme) hierdie wetenskap te beoefen nie?

(i) Neem as voorbeeld die Sterrekunde. Dit is duidelik dat die kerk nie soos in die dae van Galileo dogmatisties sy eie kosmologie sal kan of mag afdwing nie. Die vraag is egter: Het die Woord van God überhaupt iets ten opsigte van hierdie lewensgebiede te sê, en wat van die lewensgebiede van onderwys, Kuns en Letterkunde? In verband met laasgenoemde kan gevra word: Mag die Christelike Etiek vanuit Gods Woord niks oor die letterkunde sê nie? Is hierdie lewensgebied só vry, dit wil sê só outonoom dat die nomos tou Theou, die Wet van God, daarin en daaroor géén seggenskap het nie?

(ii) Van Protestantse kant is daar wel pogings om 'n antwoord van die kerk te gee op die probleem van gesekulariseerde lewensgebiede. Ek behandel hier nie van Ruler se Teokratiese gedagte nie, maar wys hier kortliks slegs op die Wysbegeerte van die Wetsidee (Dooyeweerd c.s.) én die variant van Stoker, die Wysbegeerte van die Skeppingsidee, albei uit die skool van Abr. Kuyper. Hier het ons 'n poging om alle lewensgebiede en -funksies in ' $n$ volgorde en rangorde te rangskik en om vanuit bybelsreformatoriese gesigspunt die verbande tussen hierdie lewensgebiede te bepaal en tot 'n eenheidsvisie op die lewe te kom. Die outonomie word afgewys, want volgens die wetsidee is daar geen lewensgebied waaroor die Wet en Woord van God geen seggenskap het nie en volgens die skeppingsidee is die implikasie dieselfde, want elke lewensgebied is 'n geskape werklikheid en in hierdie skeppingsorde staan elke lewensgebied onder die tug en die troos van die Woord en Wet van die soewereine Skepper van alles. Maar as die outonomie afgewys word, dan beteken dit nog nie dat elke lewensgebied nie sy eie relatiewe stukragte en norme besit nie, dat elke lewensgebied nie 'n soewereiniteit in eie kring het nie, hoewel die laere lewensgebied (bv. die estetiese, o.a. die letterkunde) staan onder die tug van die hoëre lewensgebiede (bv. die etiese en religieuse). Waardevol is o.a. ook die visie dat die geloofsgesteldheid (hier Wedergeboorte genoem) van die deelnemer aan 'n lewens- 
gebied (bv. die wetenskaplike ondersoeker) veral op geesteswetenskaplike gebied, 'n vername rol sal speel.

(iii) Nou wil ek nie beweer dat hierdie wysbegeerte sondermeer die antwoord van die kerk ten opsigte van sekularisasie is nie. Ek het alreeds van Ruler as 'n alternatiewe poging genoem, maar twee dinge is duidelik: Eerstens dat ons hier wel vanuit bybelsreformatoriese visie 'n goeddeurdagte en positiewe poging tot antwoord het, en tweedens dat die kerk sal moet probeer om aan elke lewensgebied en aan die hele gesekulariseerde kultuur van vandag te verkondig dat hulle geen outonome gode is nie, maar geskape werklikhede oor wie God en Sy Woord nie net die eerste woord nie, maar ook die laaste woord behoort te spreek.

(iv) Miskien sal ons in hierdie verkondiging goed doen om soos die sestiende-eeuse kerkhervorming te onderskei tussen die abstraksie nl. die lewensgebied (bv. die natuurwetenskap) en die mens wat in hierdie lewensgebied werksaam is (i.c. die natuurwetenskaplike) en om soos die kerkhervorming die mense in hierdie lewensgebiede as bewuste Christengelowiges te laat werksaam wees met ,innerweltliche Askese", dit wil sê as mense wat in hierdie wêreld is, maar nie van hierdie wêreld nie. En hierdie laaste is belangrik, want vanuit die eskatologie, vanuit die eintlike lewe wat alreeds met die opstanding van Christus begin het, word in werklikheid al hierdie lewensgebiede en ook die gelowige se betrokkenheid daarby, heilsaam gerelativeer. Dit is myns insiens een van die grondfoute van die Social Gospel dat dit die eskatologiese verwagting en perspektief verloor het en dus verbete by dic sosiale strukture van hierdie wêreld betrokke is om sodoende die Koninkryk van God te verruil vir 'n utopiese droom van hier-en-nou. Maar onderhewig aan hierdie eskatologiese voorbehoud waarin ons elke dag sal moet bid vir ons geestelike daaglikse brood, sal dit die taak van die kerk wees om ernstig te soek na in eenheidsvisie vanuit bybels-reformatoriese gesigspunt op al hierdie versplinterde en (in hulle oë) outonome lewensgebiede. Hierdie lewensgebiede is deur die bybelse lig van die Evan- 
gelie wel geontmitologiseer en geontdemoniseer, maar die kerk sal die mense wat daarby betrokke is, moet deurdring met die besef dat al hierdie lewensgebiede resloos en sinvol bepaal word deur God en Sy vér, vreemde wêreld en dat in al hierdie lewensgebiede God gedien en Sy eer gesoek moet word.

8. In my artikels oor die grondslae en grondstruktuur van die Kommunisme (waarvan één onder andere in Die Hervormde Teologiese Studies, 23/1, bl. 5 v.v. verskyn het) het ek aangetoon dat die Kommunistiese Ideologie die mees-gesekulariseerde lewensvisie van vandag is. Vir hulle is die enigste werklikheid stof en krag, dit wil sê hierdie sigbare, ervaarbare en kousaal-geslote wêreld en alle lewensgebiede soos bv. die kuns, die waarheid, die staat, die regspraak, die onderwys, die politiek e.s.m. kom voort uit en word sinvol bepaal, nie deur die ander wêreld van God nie, meer deur die inherente stoflike, dit wil sê ekonomiese stukragte. Ook die godsdiens is 'n blote refleksie van hierdie stoflike, dit wil sê ekonomiese faktore. Die godsdienstige wêreld is 'n bewusgefabriseerde wêreld van klatergoud met goddelike outoriteit beklee, deur die besittersklas (en dus heersersklas) uitgedink, om soos met opium die onderdrukte massas soet te hou en om hulle eie kapitalistiese posisie te beveilig. Die bestaande orde (bv. die bestaande staatsorde) word as ' $n$ heilige instelling van God met goddelike outoriteit voorgestel om die onderdruktes op hulle plek te hou en om die eie heerlike besittersposisie te verskans. Die hiernamaals is juis hiervoor gefabriseer om die haglike lot van die onderdrukte werkers enigermate te versag, want aan hulle word gesê : "Hou goeie moed, „hier beneden is't niet," maar eenmaal daarginds en daarbo sal almal gelyk wees en alles sal regkom. Geen wonder dat die godsdiens en veral die Christendom altyd 'n godsdiens van onderdruktes en slawe was nie. Maar daar moet besef word dat 'n mens net éénmaal leef en dat die heil hier is of nêrens nie. Daar is geen wetenskaplike bewys vir God en die hiernamaals nie. Trouens, 'n mens glo net omdat jy nog nie weet nie. Maar namate die kring van wetenskaplike kennis uitbrei, krimp die kring van die geloof al kleiner en kleiner. Daarom voer die Kerk bv. in Galileo se geval en vandag nog 'n verbete stryd teen sekularisasie, teen die ontrekking van die lewensgebiede aan die sakrale sfeer sodat hulle wetenskaplik, dit wil sê kousaal, eiewettelik en „diesseitig" verstaan en beleef word. Daar sal in werklikheid ook nooit 'n wetenskaplike bewys vir God en die hiernamaals wees nie, want hulle bestaan in werklikheid nie en het nog nooit bestaan nie, want hulle spruit óf uit sosiale onder- 
drukking voort óf as bygeloof uit onkunde om die wêreld te verklaar. 'n Johannesburgse engclssprekende predikant het i.v.m. die biddag vir reën dan ook gesê dat dit alleen nog in die denkwyse van die toordokter kan bestaan, want wie die natuurproses van reën verstaan, het God nie meer nodig as magiese agent om die wêreld te verklaar nie.

9. Dit is duidelik dat alle godsdienste vir die Kommunisme onder een noemer val en dat wat ons ontdemonisering en ontmitologisering genoem het, vir hulle volkome gelyk is aan die proses van sekularisasie, dit wil sê aan die proses van mondigwording en outonomie van alle lewensgebiede omdat die wetenskaplike kennis voortgaan en die klassestryd (wat vandag hoofsaaklik 'n rassestryd is) stadig ten einde loop.

10. Hier in die Kommunistiese Ideologie het ons alreeds 'n proses van sekularisasie wat nie alleen betrekking het op die loswikkeling van die lewensgebiede ten opsigte van die Christelike westerse kultuur nie, maar 'n sekularisasie wat alles prinsipieël onttrek van God, die openbaring, die Christelike geloof en die wêreld van God, Merkwaardig is dat hierdie proses in die moderne tyd ook binne die hart van die kerk in die Teologie ingetree het en sistematies uitgewerk is, $\mathrm{nl}$. in die sg. Nuwe Teologie. Hieroor het ek, bv. oor die grondslae daarvan by Bonhoeffer, Tillich en Bultmann en oor die nadere uitwerking daarvan, uitvoerig in die genoemde artikel in die "Studies" gehandel en daarom herhaal ek hier slegs kortliks dit wat myns insiens ten opsigte van ons onderhawige probleem relevant is.

(a) Die Nuwe Teologie is nie 'n abstrakte uitvindsel van 'n paar teoloë nie, maar is 'n poging van die Teologie om op in wesenlike probleem waarvoor die kerk. Teologie en Prediking van vandag staan, antwoord te gee, nl. op die probleem van hoe om die oer-oue evangelie in die kerklike verkondiging werklik $\sin$ en betekenis te laat kry vir die moderne, wetenskaplikgevormde en gesekulariseerde mens.

(b) Die antwoord wat die Nuwe Teologie op hierdie probleem gee, is dat die evangelie soos die Bybel dit beskrywe, ingebed is in die wêreldbeeld of wêreldbeelde van in vergange tydperk. Volgens hierdie ou wêreldbeeld word (soos ons alreeds aan die begin gestel het) hierdie sigbare en ervaarbare wêreld wesenlik, wat oorsprong, voortgang, sin én einddoel betref, bepaal deur 'n ander, hoër wêreld, daarbo en daarginds. Maar die moderne, wetenskaplikgevormde mens leef net in en uit 
die ervaarbare wêreld wat alle mense prinsipieël konkreet kan ervaar en logies kan bewerk. Die ander hoër wêreld (waarby God, die goeie en die bose engele, die hemel en die hiernamaals ingesluit is) kan nie as waar of vals bewys word nie en is dus in die taal van die "linguistic analysis", non-sensical, of soos die Nuwe Teologie ook sê: religieus, mities of metafisies. Die moderne mens het o.g.v. die moderne wetenskap egter finaal van hierdie religie, mitologie en metafisika afskeid geneem en as die kerk in sy verkondiging nie in die wind wil praat nie, maar werklik verlang dat die evangelie van die Bybel sin en betekenis in die lewe van die moderne mens sal kry, sal die kerk moet soek na "The secular meaning of the Gospel" soos Paul M. van Buren se boek van 1963 ook heet.

11. Hierdie "Secular meaning of the Gospel" word dan in die Nuwe Teologie byna sonder uitsondering gesien as bestaande in eksistensiële, etiese en politiek sosiale kategorieë, met die politieksosiale betekenis miskien as die mees voorkomende. Kern-tekste van die Nuwe Teologie is Joh. 14 vers $9 \mathrm{nl}$. „Wie My gesien het, het die Vader gesien" saamgelees met Matt. 25 vers 40: .Voorwaar Ek sê vir julle, vir sover julle dit (d.w.s. hierdie sosiale barmhartigheid) aan een van die geringstes van hierdie broeders van My gedoen het, het julle dit aan My gedoen". As ons God wil soek, moet ons nie mitologies of metafisies na 'n werklikheid daarbo, of aan die begin of in die sg. eindtyd soek nie, want sulke gedrogte bestaan nie wetenskaplik (en dus objektief) nie, maar ons moet na die konkrete mens Jesus kyk, en wie goed en diep na Hom kyk, ontdek sy broeder, sy naaste. Godsdiens beteken dus doodeenvoudig die aanvaarding van jou konkrete historiese roeping van naastediens tot ' $n$ beter mensheid en samelewing niks meer nie en niks minder nie. Maury het dan ook gesê: „Politics is the language of evangelism", terwyl Harvey E. Cox gesê het: Wie geloof sê, sê politiek en politiek beteken stryd vir die polis, vir 'n waarlik-menslike samelewing en stryd teenoor vooroordele, haat, ideologie, heerssug, gevestigde magsposisies en teen die Establishment, dit wil sê die bestaande orde in kerk en maatskappy. Om dus in die moderne tyd nog te wil vashou aan die sg. objektiewe bestaan van God daarbo en ' $n$ lewe daarginds, is nie net onwetenskaplike en dus onaanvaarbare mitologie en metafisika nie, maar is blatante ontduiking van jou historiese verantwoordelikheid as mens hier-en-nou. Trouens die metafisiesreligieuse begrip van God moet uitgegroei en doodgemaak word en ons moet ' $n$ Christendom opbou wat sonder religie bestaan. 
Aangesien ek in die genoemde artikel die visies van Winter, Cox e.a. noukeuriger uitgewerk het, herhaal ek dit hier nie weer nie. Ek beskou dit as genoegsaam om hier na die onlangse verklaring, oproep en boodskap van die Suid-Afrikaanse Raad van Kerke te verwys. Hulle hoofbeswaar teen afsonderlike ontwikkeling is dat hierdie beleidsrigting voorgee dat dit voorspoed, vrede en veiligheid vir alle volksgroepe bewerkstellig en waarborg. Nou sê hierdie Raad dat dit verwerplik is, want hierdie ".ideologie" stel hom in die plek van die evangelie van Jesus Christus. Maar hoe sit dié saak inmekaar? Dit is alleen moontlik as die evangelie van Jesus Christus vir hulle ' $n$ sosiale leer en program is en enige ander sosiale program as hulle $s^{\prime} n$ is dus ' $n$ konkurrent-evangelie en dus verwerplik. Hoe vér hierdie gedagtegang al deurgedring het tot in die fynste besonderhede van ons maatskaplike lewe, blyk o.a. uit 'n onlangse opmerking van Adam Small in "Kol". As rede waarom hy in Afrikaans skryf, sê Small dat hy wel satiries in Afrikaans skryf omdat hy , in 'n streep dinge in Suid-Afrika waarin ek volgens enige ordentlike begrip van beskaafdheid my eie baas móés wees, nié my eie baas is nie . . . . "Christene" het my alreeds baie aangedien ... maar ek skerm vir die beste wat die Bybel ons bied teen dié wat vir ons lieg, lieg, lieg oor daardie beste". Dit is duidelik: Die beste wat die Bybel ons aanbied is daardie begrip van beskaafdheid om in alles jou eie baas te wees, en alle ander dinge wat die sg. Christene daaruit haal is leuens, leuens en nogmaals leuens.

12. Aangesien ek dit alreeds in die genoemde artikel gedoen het, gee ek hier nie die antwoord van die kerk op hierdie twee vorms van volkome sekularisasie weer uitvoerig weer nie. Kortliks sal die antwoord van die kerk soos volg daar moet uitsien :

(a) Die kerk sal verkondigend en belydend dit as sy diepste oortuiging teenoor die Kommunisme en Nuwe Teologie moet uitspreek dat die kerk onuitwisbaar glo dat die drie-enige God van die Bybel en dat die Christelike geloof uniek is en nie maar 'n besondere konkrete "geval" van die godsdiens of godsdienstige bygeloof is nie. Daarom is die kerk diep daarvan oortuig dat die sekularisasieproses wat die Kommunisme bewustelik deurvoer én wat die Nuwe Teologie sondermeer aanvaar, geensins voortsetting is van die ontdemoniseringsproses wat by ander godsdienste en by bygeloof ontstaan, wanneer die Bybelse verkondiging daar posvat nie.

(b) Die kerk sal moet bely en verkondig dat dit resloos vashou aan die objektiewe realiteit van die enige God van 
die Bybel, aan Sy openbaring en Sy wêreld soos bv. die hiernamaals en die ewige lewe. Die kerk sal met groot stelligheid saam met I Kor. 15 moet verkondig en bely dat indien die realiteit van die opstanding uit die dode in en deur Jesus Christus se opstanding en alles wat dit impliseer, verval, dan het die kerk en die gelowige alles verloor, ook vir God.

(c) Die kerk sal teenoor die Kommunisme en Nuwe Teologie met volle geloofsoortuiging moet stel dat die christelike geloof o.g.v. die openbaring totaal iets anders is as slegs aanneem omdat ons nog nie o.g.v. wetenskaplike feite en bewysvoerings, weet nie. Dit is die oortuiging van die kerk dat al sou ek op wetenskaplike wyse alle raaisels van die skepping opgelos hê en ken, ek my nogtans in kinderlike geloofsvertroue, beide in lewe en in sterwe in die Vaderarms van God kan stel.

(d) Die kerk sal nooit moet toegee aan die eis van die Kommunisme (en die aanvaarding deur die Nuwe Teologie) om die geloofsrealiteite, wetenskaplik, diesseitig te bewys nie, want dan sal die kerk alles onherroeplik verloor. Die kerk sal, soos Karl Barth ons onlangs weer duidelik uit Gods Woord geleer het, onwrikbaar moet glo en bely dat die geloofsrealiteite uitsluitlik en alleen openbaringsrealiteite is en bly - realiteite wat slegs staan in die kontingente openbaring van die soewereine God.

(e) Teenoor die Nuwe Teologie se Social Gospel én teenoor die Kommunisme sal die kerk nooit mag toegee dat die taak van die kerk slegs "innerweltlich" en dus eties en sosiaal is nie. Die taak van die kerk sal wees om uit die vér, vreemde wêreld van God weereens met volle geloofs-oortuiging te getuig van die werklikheid van die ewige verlossing in Jesus Christus en alleen van daaruit sal die kerk met volle verantwoordelikheid en tegelyk met volle vryblywendheid ten opsigte van die wêreld, sy taak teenoor die wêreld aanvaar uit dankbaarheid tot God, tot Sy diens en eer. 